\title{
Wetdeck slamming loads on a developed catamaran hullform - Experimental investigation
}

\author{
Ahmed Swidan a,b,*, Giles Thomas c, Irene Penesis a, Dev Ranmuthugala a, Walid Amin a, Tom Allen \\ d, Mark Battley ${ }^{d}$. \\ ${ }^{a}$ Australian Maritime College, University of Tasmania, TAS 7248, Australia \\ ${ }^{b}$ Arab Academy for Science, Technology and Maritime Transport, Alexandria 1029, Egypt \\ ${ }^{c}$ University College London, London WC1E 7JE, UK \\ ${ }^{d}$ Centre for Advanced Composite Materials, University of Auckland, Auckland 1023, New Zealand
}

\begin{abstract}
Catamaran wetdeck slamming has been experimentally investigated using a servo hydraulic slam testing system. A series of controlled-speed water impacts was undertaken on a rigid catamaran bow section with two interchangeable centrebows. Entry into the body of water was at two fixed trim angles; 0 and 5 degrees. The vertical velocity was varied from 3 to $5 \mathrm{~m} / \mathrm{s}$ in $0.5 \mathrm{~m} / \mathrm{s}$ increments. This study presents a new dataset of pressure distributions and slam forces on the arched wetdeck structure of catamaran vessels. The relationships between the peak force magnitudes, relative impact angle and vertical velocity are observed, with a small reduction in slam force for an amended centrebow. Limited pressure measurements along the archway were not found to be representative of wetdeck slamming loads.
\end{abstract}

Keywords: Catamaran; Slamming forces; Pressure distribution; Water impact

\section{Introduction}

Wetdeck impulse, or slamming, is one of the principal wave-induced loads acting on high-speed catamarans while operating in rough seas. A catamaran experiences such high loads when the wetdeck, the fore deck area between the two demihulls, strikes the water at high relative velocities causing high transient pressure fields at the impact region. The wetdeck slamming loads can be in the order of the weight of the vessel or more, as stated by Kaplan (1987). Consequently these loads can cause structural damage, as reported by Rothe et al. (2001) and Thomas et al. (2002). Wetdeck slamming loads is one of the key factors in catamaran structural design (Giannotti (1975)), and in particular the wetdeck structure (Djatmiko (1992)). As most of slam loads are centered in the vicinity of the bow section (Thomas et al. (2011b)).

\footnotetext{
* Corresponding author.

E-mail address: Ahmed.Swidan@utas.edu.au (A. Swidan)
} 
For efficient structural design it is necessary to accurately predict the local wetdeck slamming loads and to understand the key elements influencing the severity of the hydrodynamic loads acting on the bow section during water impacts. Local slamming loads imposed on a hull during forward speeds can be decomposed into vectors normal and tangential to the water surface. Those tangential to the water surface are not expected to produce significant pressure loads on the hull, for example Payne (1988) observed that slam loads during a prismatic hull impacting with water are the same kind of loads it experiences during impact at speed. This assumption has been used previously to characterise slamming loads, such as for fixed cylinders subjected to wave induced slamming loads (Greenhow (1987)).

There are two vertical-water-impact experimental techniques that are generally used to characterise slamming loads: free-fall drop tests and controlled speed water impacts. Free fall drop tests allow the test model to fall under gravitational forces into the water. Free fall experiments have been performed by Chuang and Milne (1971), Ochi and Motter (1973), Engle and Lewis (2003), Yettou et al. (2007), De Backer et al. (2009), Lewis et al. (2010), Van Nuffel et al. (2013), Van Nuffel et al. (2014), Panciroli and Porfiri (2013) and Jalalisendi et al. (2015). The controlled speed water-impact experiments technique requires a more sophisticated experimental set-up in order to achieve model-water impact at constant speeds, such as those conducted by Alaoui et al. (2012), Alaoui et al. (2015), Tassin et al. (2012), Battley et al. (2005), Battley and Allen (2012) and Stenius et al. (2013).

In general, there is a lack of non-proprietary data suitable for investigating catamaran vessel water impacts. Davis et al. (2007) performed a series of free-fall drop tests on a quasi-two-dimensional (2-d) catamaran section and this data was used to validate numerical simulations conducted by Swidan et al. (2014). One of the limitations in using free-fall drop tests is the rapid deceleration of the model during water-impacts, which may not be the case for large high-speed ships (such as large catamarans) during water-entry (Tveitnes et al. (2008) and (Panciroli and Porfiri (2013)). In addition Ochi and Motter (1973) and Davis and Whelan (2007) concluded that the results of 2-d drop test experiments in general overestimate the pressure peaks magnitude (by more than three times), so simplifying the wetdeck slam phenomenon as a quasi-2-d problem can be considered to be an invalid assumption for such hull forms (Swidan et al. (2016)). 
An initial experimental study into vertical water impact tests on a generic 3-d catamaran model at a range of impact velocities and a fixed $0^{\circ}$ angle of trim was conducted by Swidan et al. (2016). This data was used to successfully validate numerical simulations by Swidan et al. (2015) with respect to both the slamming force and the pressure distributions.

This paper reports on an extension of the work by Swidan et al. (2016) by studying key elements influencing slamming load distributions and magnitudes on the catamaran wetdeck. In the next section the test setup is discussed, and a catamaran hull model with two interchangeable centrebows is presented. The pressure distribution along the wetdeck and the slamming forces on the entire model are measured directly during water-entry with two trim angles of $0^{\circ}$ and $5^{\circ}$ and at a range of vertical constant speeds (from 3 to $5 \mathrm{~m} / \mathrm{s}$ in $0.5 \mathrm{~m} / \mathrm{s}$ increments). This allowed a study into the influence of the relative impact angle, velocity and water-flow separation on vertical force, slamming occurrence and pressure distributions.

\section{Model and Experimental setup}

\subsection{The test system}

A catamaran model was tested using the Servo-Hydraulic Slam Testing System (SSTS). This controlled-speed facility is discussed in detail by Stenius et al. (2013), Battley and Allen (2012), Battley et al. (2005) and Swidan et al. (2016) and is illustrated in Fig. 1. 


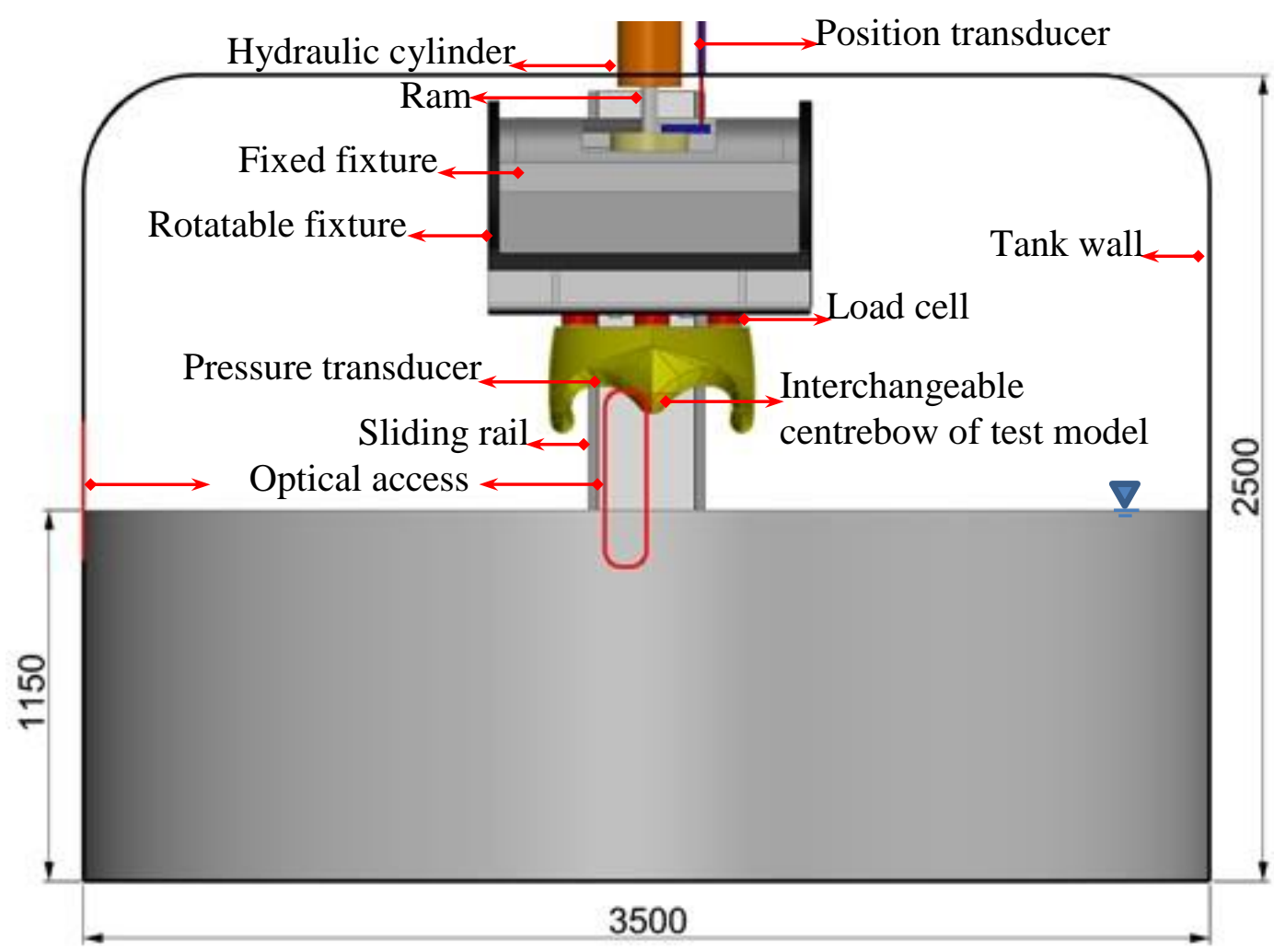

Fig. 1: General test arrangement. Showing the main components of SSTS and the instrumented model (dimensions in $\mathrm{mm}$ ).

For the purpose of the present study, the impacts were conducted with the model at two fixed trim angles $(\theta)$ of $0^{\circ}$ and $5^{\circ}$. To allow the model to trim by the bow by an angle $\theta$ of $5^{\circ}$ a set of four wedges were fixed between the ram fixture (two stiffened $5 \mathrm{~mm}$ Aluminium L-sections) and a stiffened plate that connected the load cells to the model, as illustrated in Fig. 2.

The water depth and temperature during tests were approximately $1.15 \mathrm{~m}$ and $11^{\circ}$ respectively. All tests were performed in a controlled environment and with an initially calm water-surface. 


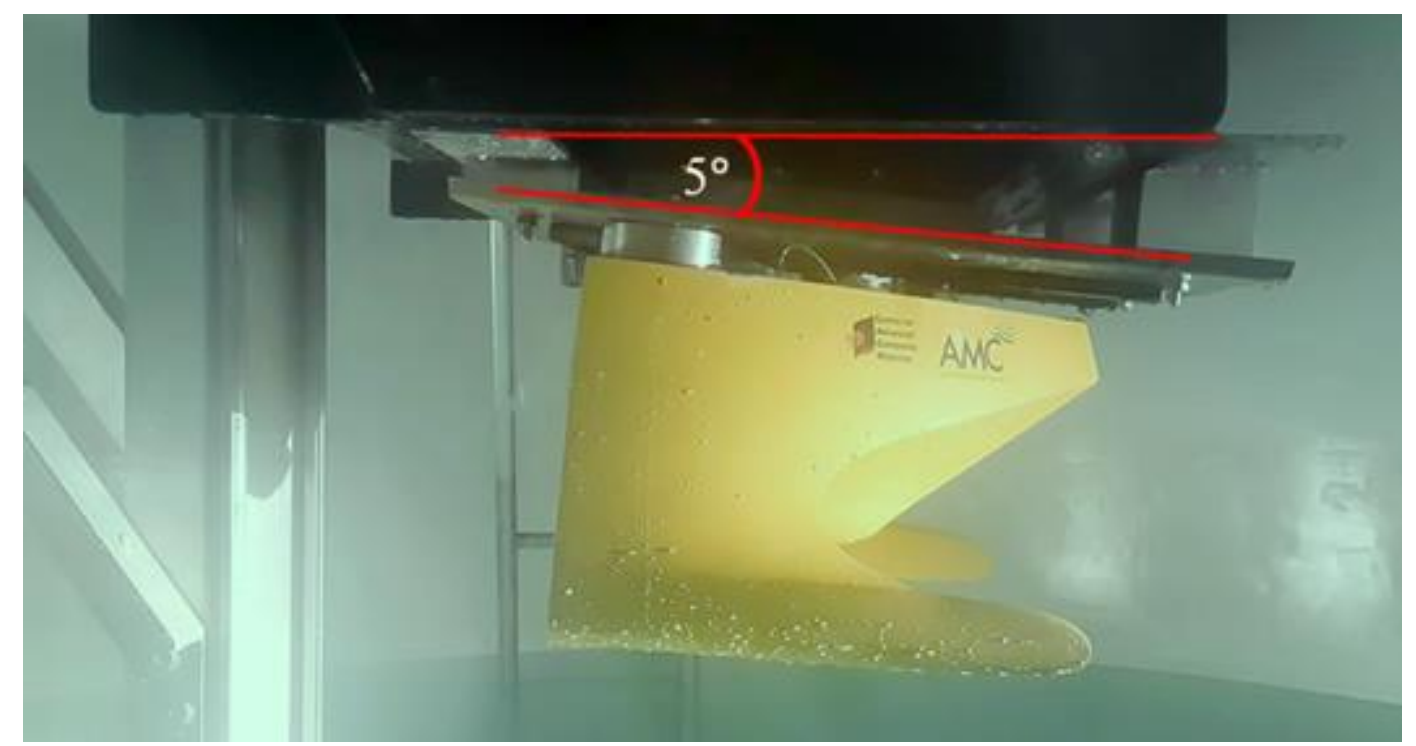

Fig. 2: Tested model installation at $5^{\circ}$ angle of trim (bow-down), showing two wedges between the rig and a stiffened support.

\subsection{Instrumentation}

To acquire the measured data, a modular National Instruments ${ }^{\mathrm{TM}}$ compact data acquisition system (NI cDAQ 9178) and National Instruments LabVIEW software were used. The system recorded all measured data (immersion, pressure and total force) at its maximum sampling rate of $51.2 \mathrm{kHz}$ for all channels to provide sufficient density of data points especially for the pressure peaks (DNV (2010)). A summary of the instruments and associated systematic errors is given in Table 1. In addition a highspeed video camera (Photron Fastcam SA5 model) with a frame rate of $7500 \mathrm{fps}$ and a 1 Mpixels resolution was utilised to film the wetdeck slamming event. Further details on the instrumentation can be found Swidan et al. (2016), Allen (2013), and Battley and Allen (2012).

In Fig. 3 the model is shown at zero trim $\left(\theta=0^{\circ}\right)$ which corresponds to a relative impact angle $\beta$ (between the archway of the wetdeck and the undisturbed water surface) of $11^{\circ}$. The figure also provides the locations of the five pressure transducers and three load cells. 
Table 1: Summary of Instruments

\begin{tabular}{lllll}
\hline Gauge & $\begin{array}{l}\text { No. of } \\
\text { Channels }\end{array}$ & Manufacturer & Model & $\begin{array}{l}\text { Maximum } \\
\text { Range } \\
\text { (Unit) }\end{array}$ \\
\hline Load cell & 3 & $\begin{array}{l}\text { Precision } \\
\text { transducers }\end{array}$ & LPC 5t & $5000(\mathrm{~kg})$ \\
\hline $\begin{array}{l}\text { Pressure } \\
\text { Transducers }\end{array}$ & 5 & PCB & 113 B 26 & 68950 \\
\hline Position & 1 & Piezotronics & & $\left(\mathrm{kNm}^{-2}\right)$ \\
sensor & Vishay & REC 139 & $3(\mathrm{~m})$ \\
\hline
\end{tabular}
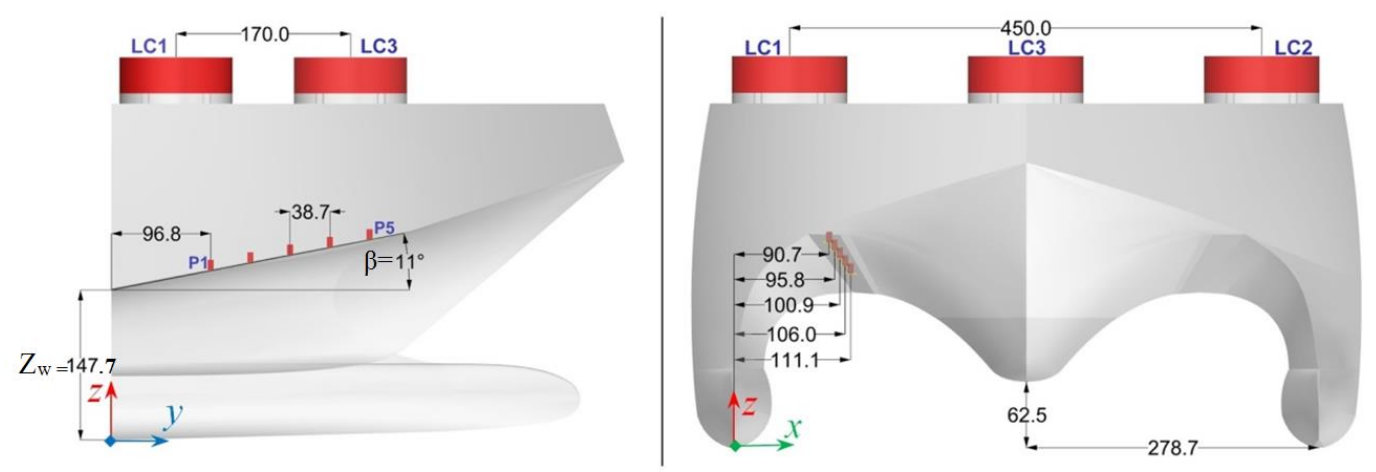

Fig. 3: Schematic diagram of profile and bow views of the parent model at $\theta=0^{\circ}$, showing locations of the used pressure transducers and load cells (LCi).

\subsection{The test model}

The lines plan of the wave-piercer catamaran hullform model is illustrated in Fig.4. This model was built with two interchangeable centrebows that can be attached to the main body, as shown in Figs. 4-6. The main particulars of the test model are given in Table 2. The details of the model structure and construction can be found in Swidan et al. (2016). 


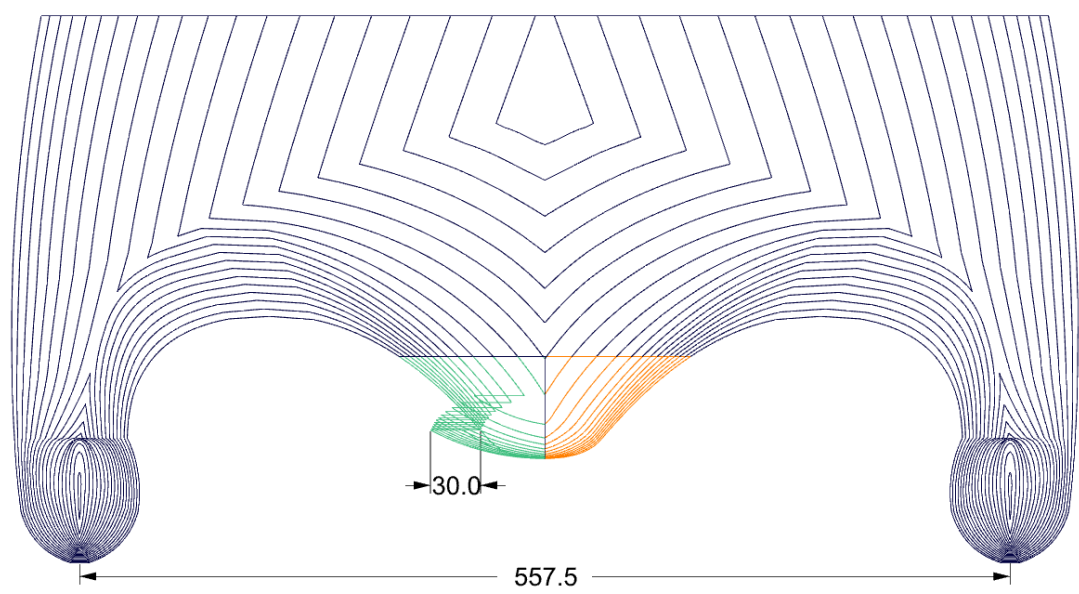

Fig. 4: Catamaran body lines with two interchangeable centrebows. showing the parent centrebow lines illustrated in orange on the right and the amended centrebow lines presented in green on the left.

The parent hull form is a generic wave-piercer catamaran (presented in orange lines in Fig. 4), similar in style to those designed by Revolution Design Pty Ltd and manufactured by Incat Tasmania. The second winged-centrebow (named in this study amended hull) is a proposed new design for the centrebow and aims to induce water separation at the tip of wings during water entry, as presented in Fig. 6. The objective of this early water separation is to generate an air cavity that can work as damper during wetdeck slamming. Another feature is the larger exposed area with a reduced deadrise angle to try and provide greater resistance during water-entry and reduce the impact velocity. Additionally the winged shape of the amended centrebow is designed to increase the drag force during water-exit after slamming events, reducing the pitch motions.

Table 2: Test model main particulars

\begin{tabular}{lll}
\hline Length over all $(\mathrm{mm})$ & 500 & \\
Beam $(\mathrm{mm})$ & 628 & \\
Height $(\mathrm{mm})$ & 327.6 & \\
Displacement $(\mathrm{kg})$ & 14.8 & \\
Relative impact angles $\left(\theta^{\circ}\right)$ & 0 & 5 \\
Depth to the wetdeck $(\mathrm{mm})$ & 147.72 & 168.3 \\
Depth to the centrebow $(\mathrm{mm})$ & 62.52 & 71.75 \\
\hline
\end{tabular}




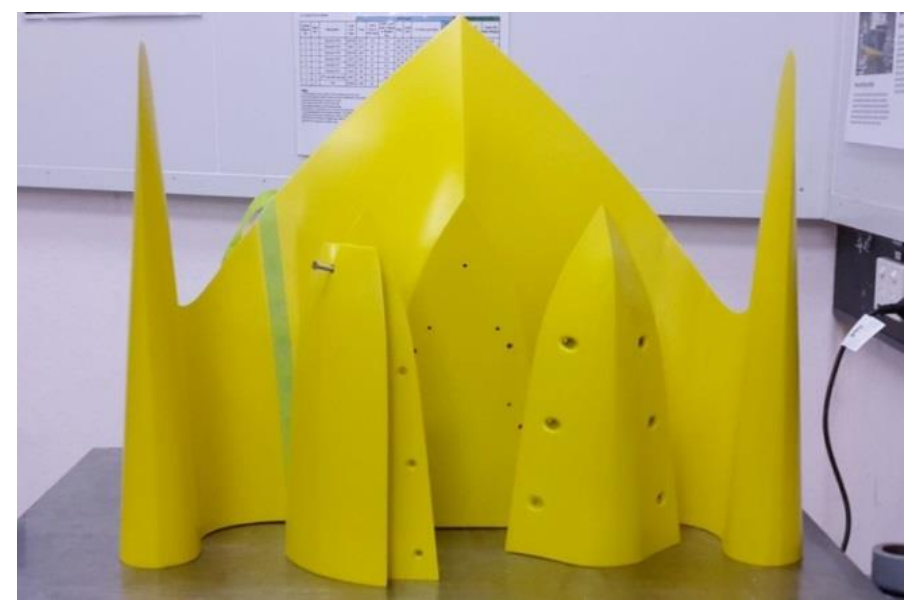

Fig. 5: Catamaran test-model, showing the main hull and the two interchangeable centrebows.

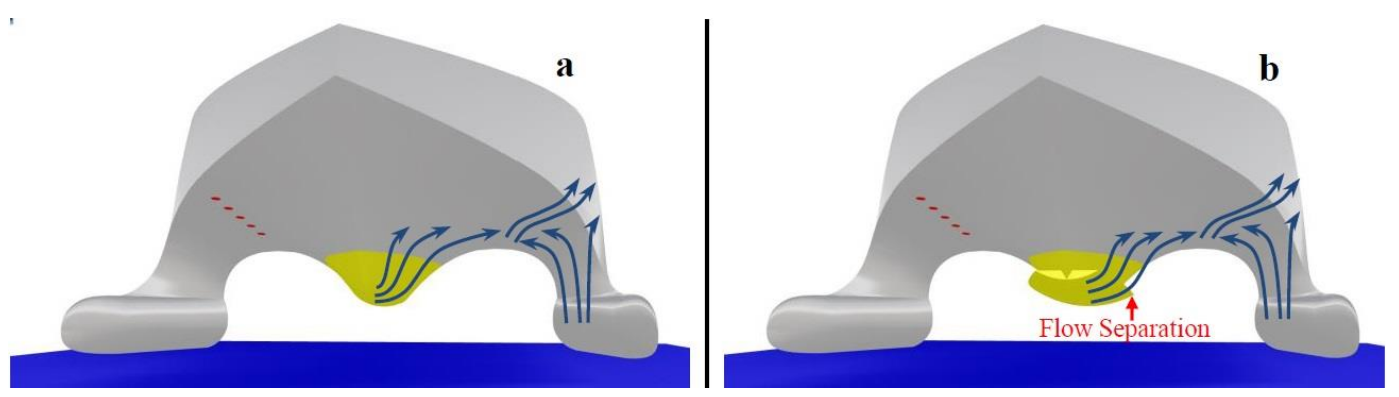

Fig. 6: Schematic chart showing the five pressure transducers (red surface) on the starboard side and the anticipated flow behaviour on one side during water penetration of; (a) parent centrebow and (b) amended centrebow.

\subsection{Test conditions}

The test conditions for a total of 64 water-impact experiments discussed in the following sections are outlined in Table 3, each test condition was repeated at least 3 times and the repeatability of the complete system set up was confirmed by Swidan et al. (2016). Between tests at least 15 minutes was allowed to ensure that the water surface was calm.

The range of impact velocities was primarily selected based on Froude scaling of full-scale slam events measured and analysed by Jacobi et al. (2014), which stated that the relative vertical velocities could reach $13 \mathrm{~m} / \mathrm{s}$, which is equivalent to $3.5 \mathrm{~m} / \mathrm{s}$. The trim angle of $5^{\circ}$ was selected on the basis of past model seakeeping tests conducted by 
Lavroff et al. (2013) on a 112m INCAT catamaran, which showed that the peak pitch angle of a $2.5 \mathrm{~m}$ catamaran model could reach a maximum of $5.1^{\circ}$.

Table 3: Test conditions

\begin{tabular}{|c|c|c|c|c|c|c|c|c|c|c|c|c|c|c|c|c|c|c|c|c|}
\hline $\begin{array}{c}\text { Hull } \\
\text { shane }\end{array}$ & \multicolumn{10}{|c|}{ Parent hull } & \multicolumn{10}{|c|}{ Amended hull } \\
\hline$\theta^{\circ} / \beta^{\circ}$ & \multicolumn{5}{|c|}{$0 / 11$} & \multicolumn{5}{|c|}{$5 / 6$} & \multicolumn{5}{|c|}{$0 / 11$} & \multicolumn{5}{|c|}{$5 / 6$} \\
\hline $\begin{array}{c}\text { Condition } \\
\text { No. }\end{array}$ & 1 & 2 & 3 & 4 & 5 & 6 & 7 & 8 & 9 & 10 & 11 & 12 & 13 & 14 & 15 & 16 & 17 & 18 & 19 & 20 \\
\hline $\begin{array}{l}v_{\text {target }} \\
{[\mathrm{m} / \mathrm{s}]}\end{array}$ & 3 & 3.5 & 4 & 4.5 & 5 & 3 & 3.5 & 4 & 4.5 & 5 & 3 & 3.5 & 4 & 4.5 & 5 & 3 & 3.5 & 4 & 4.5 & 5 \\
\hline
\end{tabular}

\section{Results and discussion}

This section presents and discusses the results of test conditions given in Table 3. Table 4 presents the mean values of;
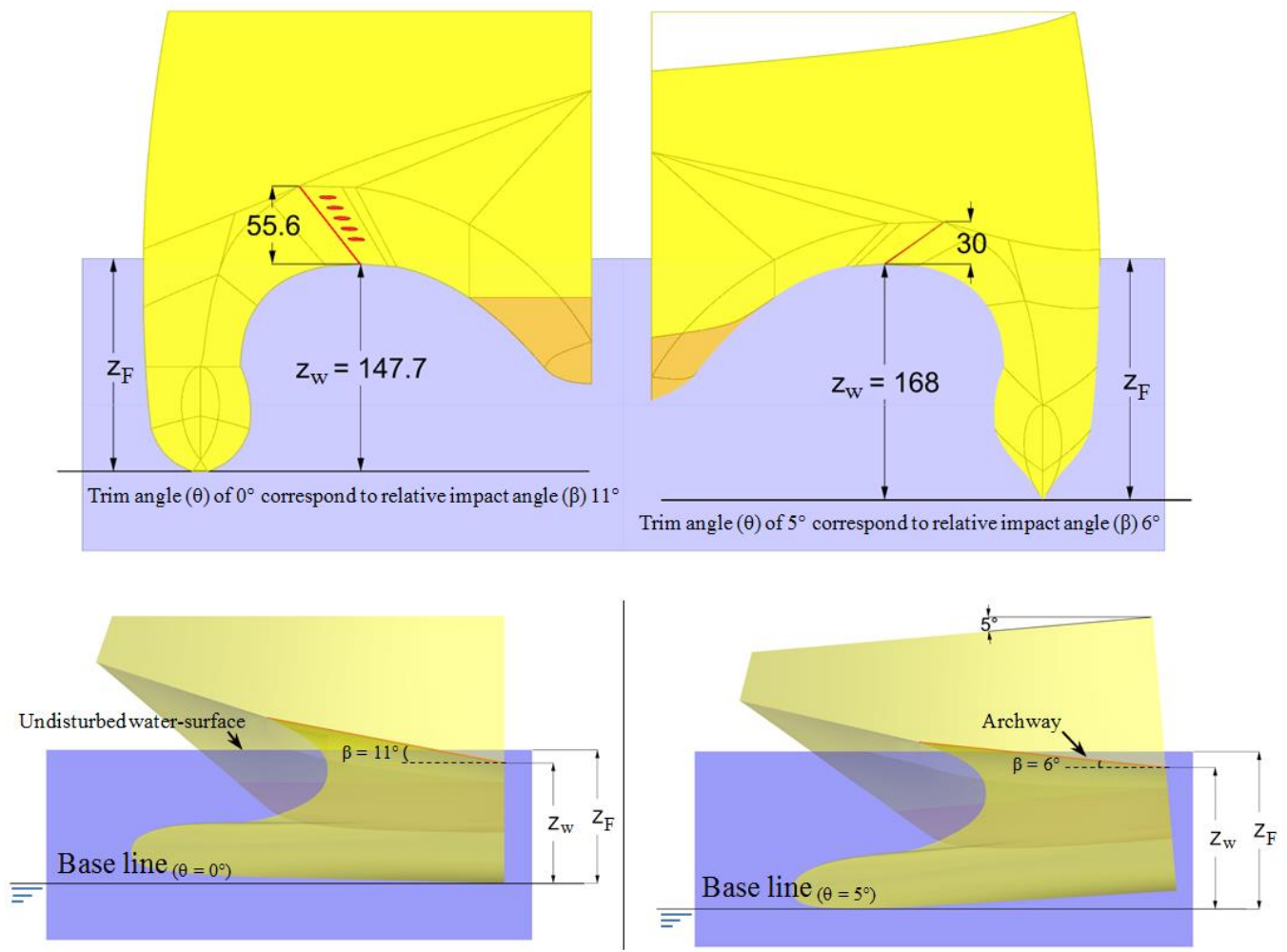

Fig. 7: Bow and profile views of model at trim angles of 0 and 5 degrees corresponding to two relative impact angles $(\beta)$ of 11 and 6 degrees. It shows the red reference line on the archway that represents the highest section along the top of the $\operatorname{arch} w a y . z_{\mathrm{w}}\left(\theta^{\circ}\right)$ is the vertical distance between the initial calm water-surface and the highest point on the wetdeck at the aft end of the centrebow and $z \mathrm{~F}\left(\theta^{\circ}\right)$ which corresponds to the immersion at which the maximum slam force occurs. 
- impact velocities $\left(v_{\theta^{\circ}}\right)$, immersion $\left(Z_{\theta^{\circ}}\right)$ (see Fig. 7) and timings $\left(\delta t_{\theta^{\circ}}\right)$ from $t_{0}=0$ $\mathrm{s}$ at which demi hull keels touch the free-surface to the timing at which slam force peaks.

- maximum force and pressure magnitudes.

Table 4: Summary of results

\begin{tabular}{|c|c|c|c|c|c|c|c|c|c|c|c|}
\hline \multirow[t]{2}{*}{ Hull Model } & \multirow[t]{2}{*}{$\begin{array}{l}v_{\text {target }} \\
{[\mathrm{m} / \mathrm{s}]}\end{array}$} & \multicolumn{2}{|c|}{$\begin{array}{c}v_{\text {impact }} \\
\left(v_{\theta^{\circ}}\right) \\
{[\mathrm{m} / \mathrm{s}]}\end{array}$} & \multicolumn{2}{|c|}{$\begin{array}{l}\text { Immersion } \\
\left(Z_{F \theta^{\circ}}\right)[\mathrm{mm}]\end{array}$} & \multicolumn{2}{|c|}{$\begin{array}{l}\delta t_{\left(\theta^{\circ}\right)} \\
{[m s]}\end{array}$} & \multicolumn{2}{|c|}{$\begin{array}{c}F_{\max \left(\theta^{\circ}\right)} \\
{[k N]}\end{array}$} & \multicolumn{2}{|c|}{$\begin{array}{c}P_{\max \left(\theta^{\circ}\right)} \\
{[k P a]}\end{array}$} \\
\hline & & $v_{0^{\circ}}$ & $v 5^{\circ}$ & $Z_{F 0^{\circ}}$ & $Z_{F 5^{\circ}}$ & $\delta t_{0^{\circ}}$ & $\delta t_{5^{\circ}}$ & $F_{0^{\circ}}$ & $F_{5^{\circ}}$ & $P_{0^{\circ}}$ & $P_{5^{\circ}}$ \\
\hline \multirow{5}{*}{ Parent } & 3 & 2.8 & 2.7 & 157 & 163 & 52.86 & 55.4 & 4.3 & 5.73 & 129 & 162 \\
\hline & 3.5 & 3.2 & 3.2 & 157 & 166 & 45.76 & 48.75 & 5.8 & 7.84 & 155 & 234 \\
\hline & 4 & 3.7 & 3.7 & 157 & 171 & 40.4 & 43.84 & 7.6 & 10.3 & 210 & 277 \\
\hline & 4.5 & 4 & 4 & 158 & 173 & 36.7 & 40 & 9.4 & 12.3 & 299 & 351 \\
\hline & 5 & 4.5 & 4.4 & 160 & 177 & 33.5 & 37.2 & 11.9 & 14.3 & 316 & 406 \\
\hline \multirow{5}{*}{ Amended } & 3 & 2.75 & 2.8 & 161 & 164 & 54.74 & 56.5 & 4 & 5.1 & 154 & 197 \\
\hline & 3.5 & 3.2 & 3.3 & 160 & 166 & 47 & 48.6 & 5.2 & 7.4 & 205 & 242 \\
\hline & 4 & 3.7 & 3.7 & 154 & 169 & 39.66 & 43.5 & 7 & 9.7 & 248 & 313 \\
\hline & 4.5 & 4.1 & 4.1 & 158 & 178 & 36.4 & 41 & 9.3 & 12.2 & 316 & 372 \\
\hline & 5 & 4.5 & 4.5 & 162 & 179 & 34 & 37 & 11.2 & 14.1 & 376 & 457 \\
\hline
\end{tabular}

\subsection{Slamming Force}

This section discusses in detail the influence of the differing centrebows, vertical velocity and impact angle on the slamming force.

\subsubsection{Slam force time-history}

The results from two water-impact tests at a target velocity of $4 \mathrm{~m} / \mathrm{s}$ using both centrebows at a fixed $\theta=5^{\circ}$ are compared and presented in Figs. 8 and 9. Fig. 8 includes; (a) vertical velocity and (b) total vertical slam force.

In Fig. 8(a) the measured velocities for both the parent and amended models are shown to be in good agreement, with a maximum variation of approximately $6 \%$ (3.6 
$\mathrm{m} / \mathrm{s}$ ) around the mean value of $3.85 \mathrm{~m} / \mathrm{s}$ at an immersion of approximately $175 \mathrm{~mm}$ for both centrebows.
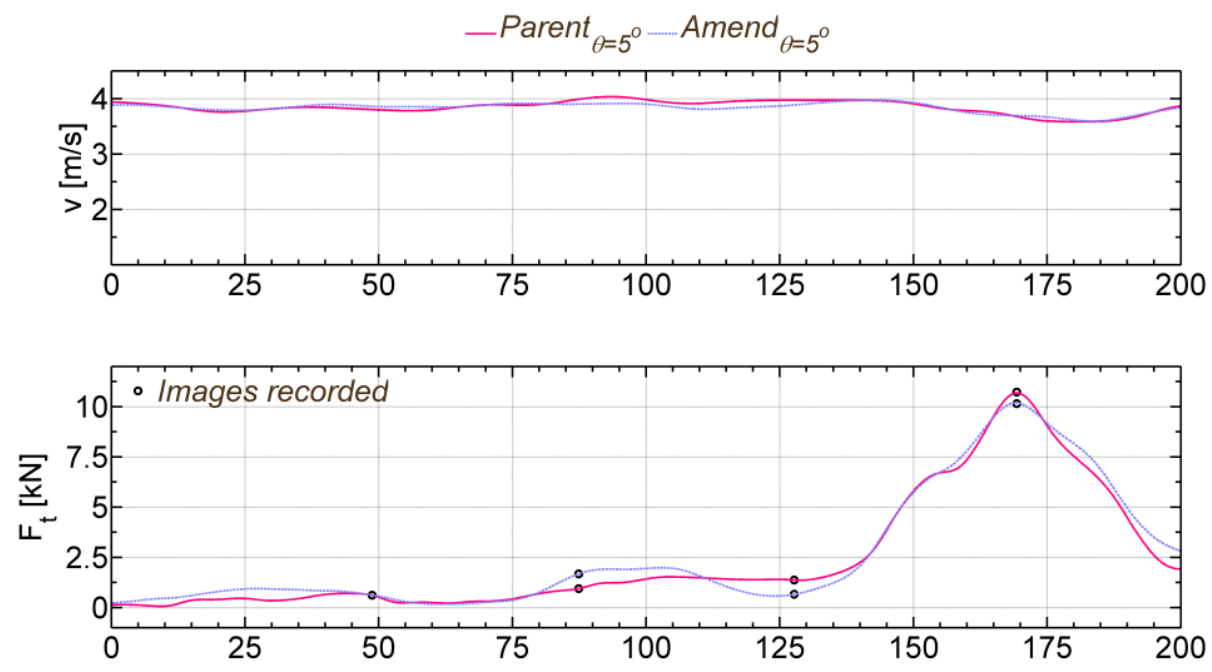

Fig. 8: Comparison between using parent against amended centrebows for a target relative velocity of $4 \mathrm{~m} / \mathrm{s}$ at $\theta=5^{\circ}$. Subplots illustrate time histories of (a) measured velocities, (b) total slam force.

Fig. 8(b) illustrates a small drop in the force traces at an immersion of $55 \mathrm{~mm}$, attributed to the "internal knuckles" of demihulls, as illustrated also in Fig. 13. These knuckles cause water-flow separation, momentarily reducing the force. A similar effect for flared amended centrebow can be seen at an immersion of $110 \mathrm{~mm}$. This shows that any flow separation occurring during water-entry is followed by a reduction in the slamming forces.

Immersion of the centrebows occurs at a nominal immersion of $87.5 \mathrm{~mm}$, as illustrated in Fig. 9. Fig. 12(b) shows the slam force increases at this time. There is a greater increase for the amended centrebow (by 85\%), which has a lower deadrise of $3.5^{\circ}$ than the parent of $23^{\circ}$.

Fig. 9 shows greater disturbance of the water-surface for the entry of the amended centrebow than the parent at an immersion of $128 \mathrm{~mm}$. Thus a larger air cushion beneath the wetdeck was expected during wetdeck-water impact for the amended hull.

The most severe slam force occurs at $169 \mathrm{~mm}$ of immersion when the archway is filled with water. The amended hull shows a reduction in slam force peak magnitude in 
the order of $6 \%$, compared to the parent hull. This reduction can be attributed to an increase in air-cushioning between the wetdeck and the water surface.

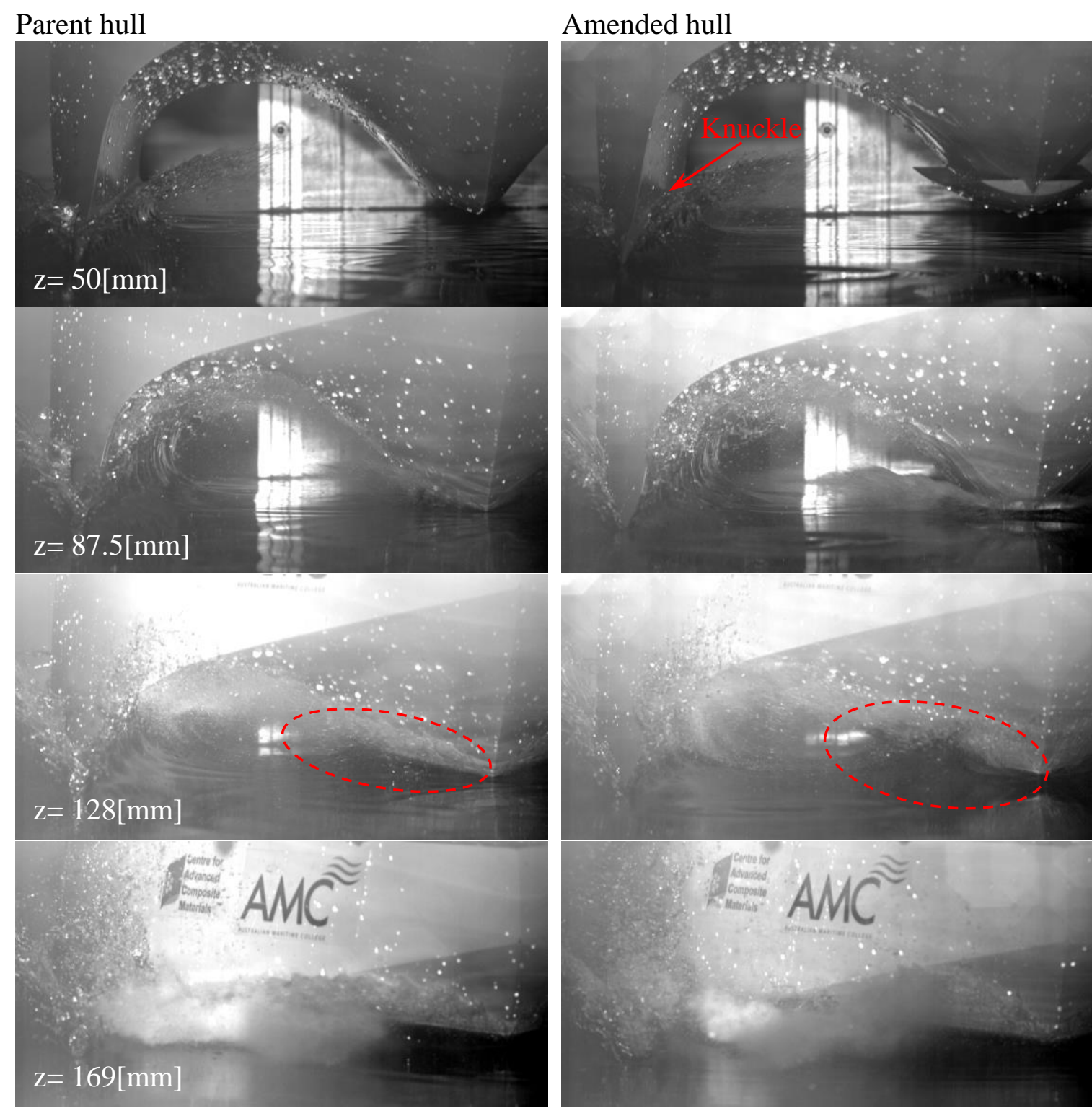

Fig. 9: Flow visualisation time history for; parent and amended centrebows hull at $\theta=$ $5^{\circ}$ and impact velocity of $4 \mathrm{~m} / \mathrm{s}$.

\subsubsection{Slam force magnitude}

Slam force should be proportional to the velocity squared Ge (2002). Fig.10. presents the peak slam forces and the corresponding fitted linear curves for all conditions (given in Table 3) against the square of the instantaneous vertical velocity.

A strong correlation between the peak slam force and the relative water-entry angle and vertical velocities is observed. The measured slam force peak measurements 
collapse well along the fitted linear trend lines with a maximum variation of $\pm 4.1 \%$, as given in Table 5.

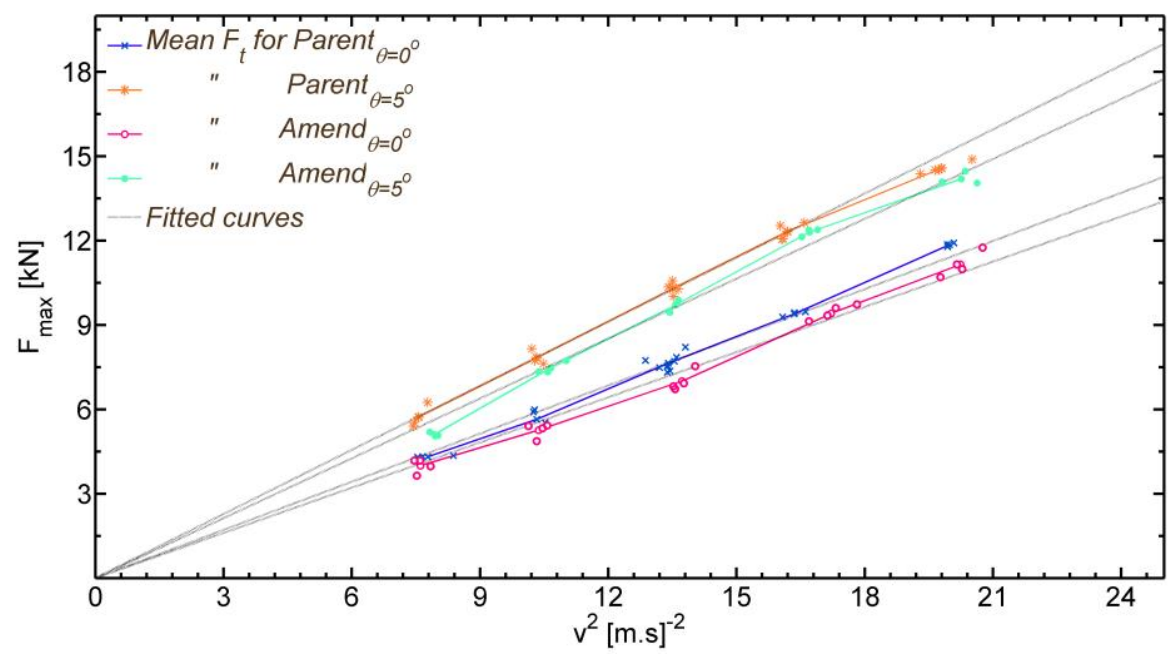

Fig. 10: Relationships of slam force peaks against the relative impact angles and the corresponding relative velocity for both centrebows.

The fitted relationships of slam force for $\theta=5^{\circ}$ is $30 \%$ higher than for $\theta=0^{\circ}$, as given in Table 5. The increase in the slam force peaks was investigated through analysing the outputs of the used three load cells, as shown in Figs. 3 and 11.

Fig. 11 presents the outputs from three load cells for $5 \mathrm{~m} / \mathrm{s}$ impacts of the parent hull form at $\theta=0^{\circ}$ and $\theta=5^{\circ}$. For the impact at $\theta=5^{\circ}$ the timing of the peak force at the bow of the model (LC3) closely correlates with the timing of the load cells at the rear of the model (LC1 and LC2). This indicates a more instantaneous peak force, supporting the traces seen in Fig. 12. The timing of the peak forces between fore and aft don't correlate for the impacts at $\theta=0^{\circ}$, indicating the centre of pressure progresses across the model, i.e., the wetdeck slamming force magnitude depends strongly on the wetted area subjected to slam force. The results also demonstrate that the smaller the relative impact angle $(\beta)$, the sharper the total slam force trace and the more significant the force peak, as presented in Figs. 11 and 12.

Table 5: Summary of expressions derived for maximum slam forces based on relative impact angles and impact velocities. 


\begin{tabular}{llll}
\hline Relative impact angle $(\theta)$ & Hull model & Peak slam-force [N] & Deviation Bounds\% \\
\hline \multirow{2}{*}{$0^{\circ}$} & Parent & $\mathrm{F}=571 v^{2}$ & $\pm 3.4 \%$ \\
& Amended & $\mathrm{F}=536 v^{2}$ & $\pm 3.7 \%$ \\
\hline \multirow{2}{*}{$5^{\circ}$} & Parent & $\mathrm{F}=760 v^{2}$ & $\pm 4.1 \%$ \\
& Amended & $\mathrm{F}=710 v^{2}$ & $\pm 5 \%$ \\
\hline
\end{tabular}
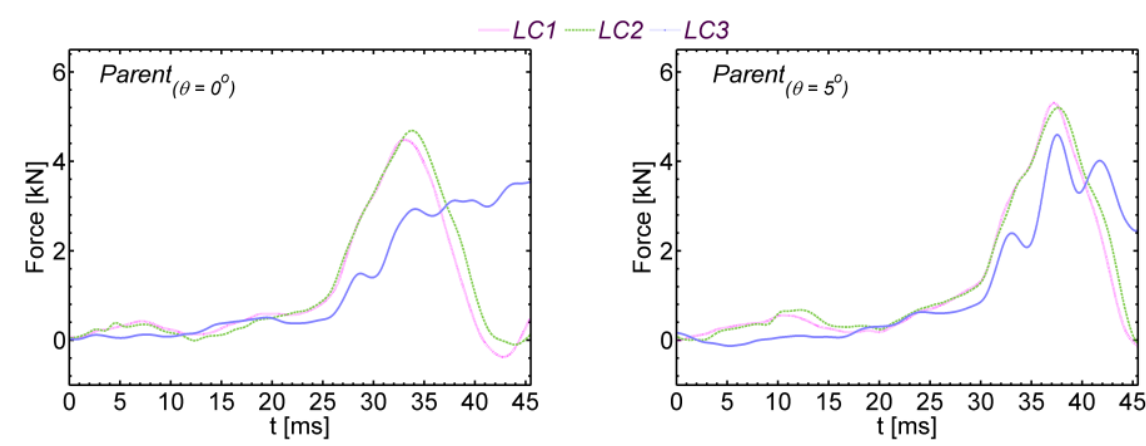

Fig. 11: Time histories of; LC1 = load cell No.1, LC2 = load cell No.2 and LC3 = load cell No.3 for a target velocity of $5 \mathrm{~m} / \mathrm{s}$ and at two relative impact angles.

The mean slam force peak magnitude is $6 \%$ lower for the amended hull, as presented in Fig. 10 and given in Table 5. This is attributed to the higher air-cushioning effect from the amended centrebow.

It is proposed that one of the limitations of using constant speed water-entry systems to compare different hull forms is that the instantaneous impact velocity remains approximately constant all hull models, despite the variation in impact force. If tested using a free-fall system or seakeeping experiments, the relative instantaneous impact velocity would change. 

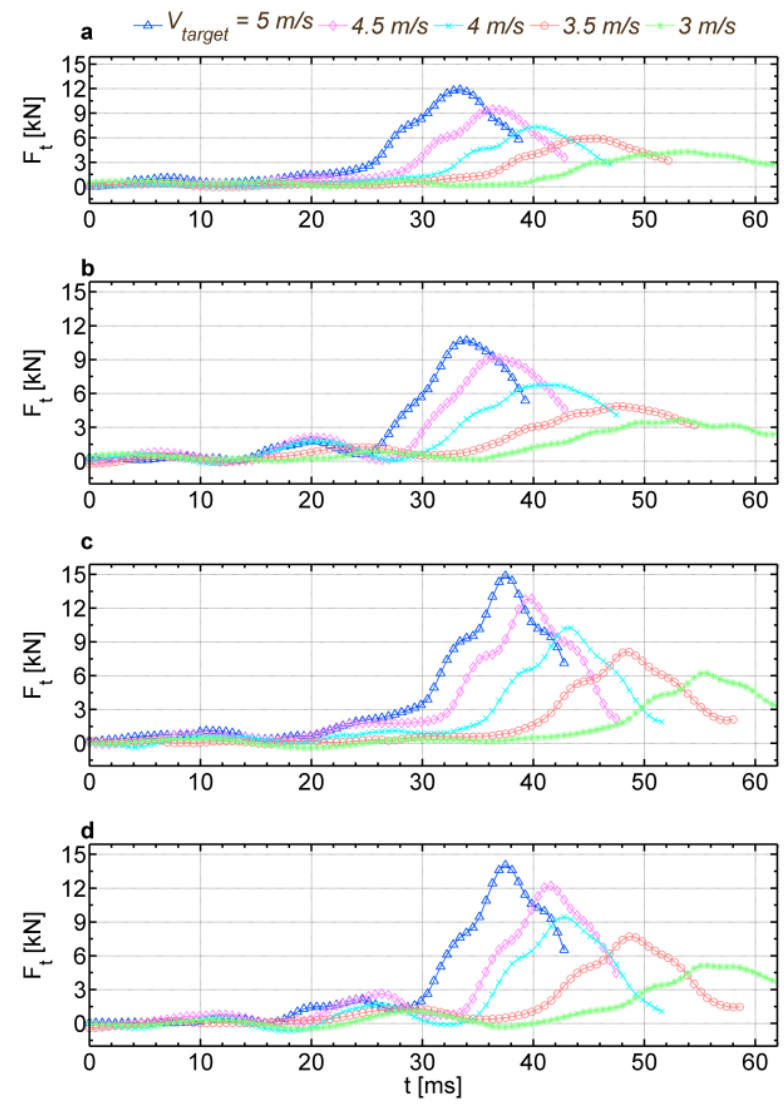

Fig. 12: Total hydrodynamic load time-histories for; (a) parent hull at $\theta=0^{\circ}$, (b) amended hull at $\theta=0^{\circ}$, (c) parent hull at $\theta=5^{\circ}$, (d) amended hull at $\theta=5^{\circ}$.

\subsubsection{Occurrence of slam force}

This section investigates the factors affecting the corresponding immersion to the slam force peak. Fig. 13 presents the total vertical slam forces acting on the entire model are against non-dimensional ratio of $z \mathrm{~F} / z_{\mathrm{w}}$ as presented in Fig. 7, where $z \mathrm{~F} / z_{\mathrm{w}}=1$ at wetdeck submergence. The general trend is for an increase in impact velocity to delay the occurrence of the peak slam force to a deeper immersion.

For all impacts at $\theta=0^{\circ}$ the maximum slam force occurs while the wetdeck is partially submerged, i.e. $z_{\mathrm{F} / z_{\mathrm{w}}}>1$ as presented in Fig. 13. This figure also demonstrates that at $\theta=5^{\circ}$ while relatively low velocity impacts ( 3 and $3.5 \mathrm{~m} / \mathrm{s}$ ) slam force peaks prior to theoretical immersion $\left(z_{\mathrm{F} / z_{\mathrm{w}}}<1\right)$, this is likely due to water pile-up reaching the wetdeck prior to the theoretical immersion depth. 


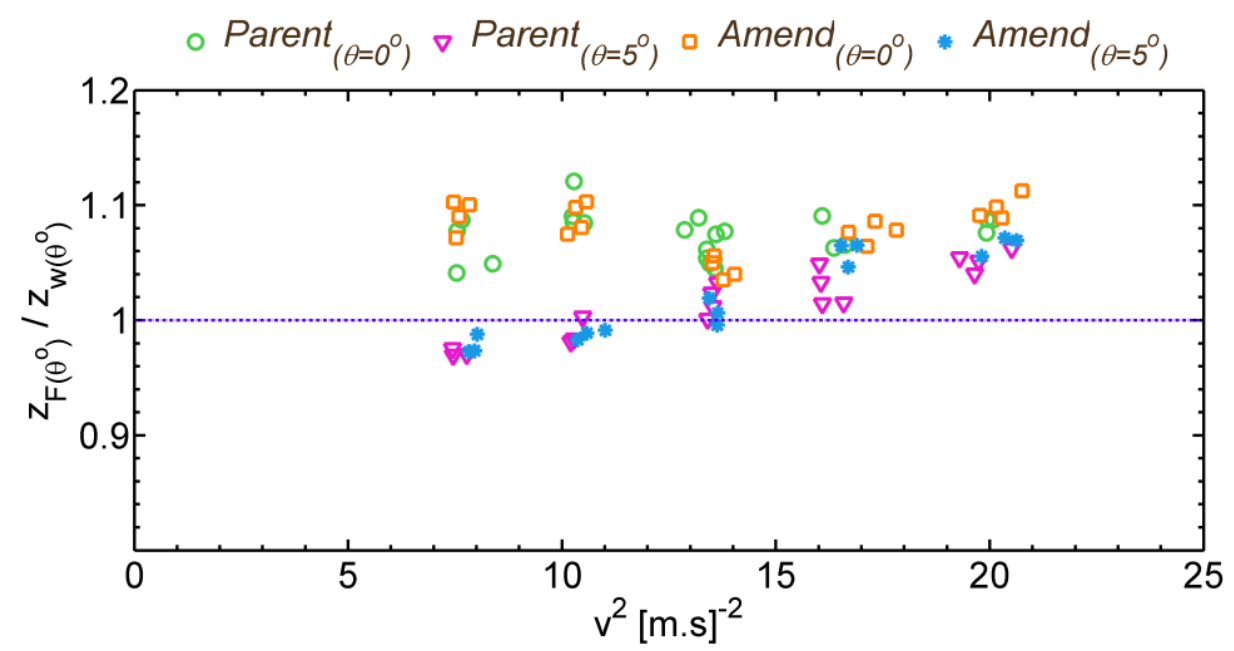

Fig. 13: Cross plot of slam force peaks against dimensional $\mathrm{z}_{\mathrm{F}} / \mathrm{Z}_{\mathrm{w}}$ for; (a) parent hull at $\theta$ $=0^{\circ}$, (b) amended hull at $\theta=0^{\circ}$, (c) parent hull at $\theta=5^{\circ}$, (d) amended hull at $\theta=5^{\circ}$.

This agrees with the observations in Thomas et al. (2011a) that the immersion at which slam force peaks is a function of the water-entry velocity, however does not agree with the proposed assumption of 2-d filling by Lavroff (2009) and Thomas et al. (2011b). It can be considered therefore that if the relative impact angle is small then the free-surface deformation beneath the wetdeck is higher and its effect decreases with as the relative vertical velocity increases. This could explain the conflict between previously conducted experiments using 2 - $d$ free-falling technique (with $0^{\circ}$ relative impact angle) and seakeeping tests with variable pitching angles, such as conducted by French (2012).

\subsection{Pressure distribution}

Fig. 14(a-e) presents the mean peak pressures for target velocities from 3 to $5 \mathrm{~m} / \mathrm{s}$ in $0.5 \mathrm{~m} / \mathrm{s}$ increments. For the parent hull at $\theta=0^{\circ}$ and $5^{\circ}$, and the amended hull at $\theta=0^{\circ}$, the maximum peak pressure is measured at P1. Then, as the slam pressure moves towards the bow, the peak magnitude decreases. At $\theta=0^{\circ}$, differences of more than 50 $\%$ are observed in Fig. 14. For the parent hull at $\theta=5^{\circ}$ the pressure peak differences tend to be less than $35 \%$, likely linked to the lower relative impact angle (dead rise angle) at the pressure transducers. 

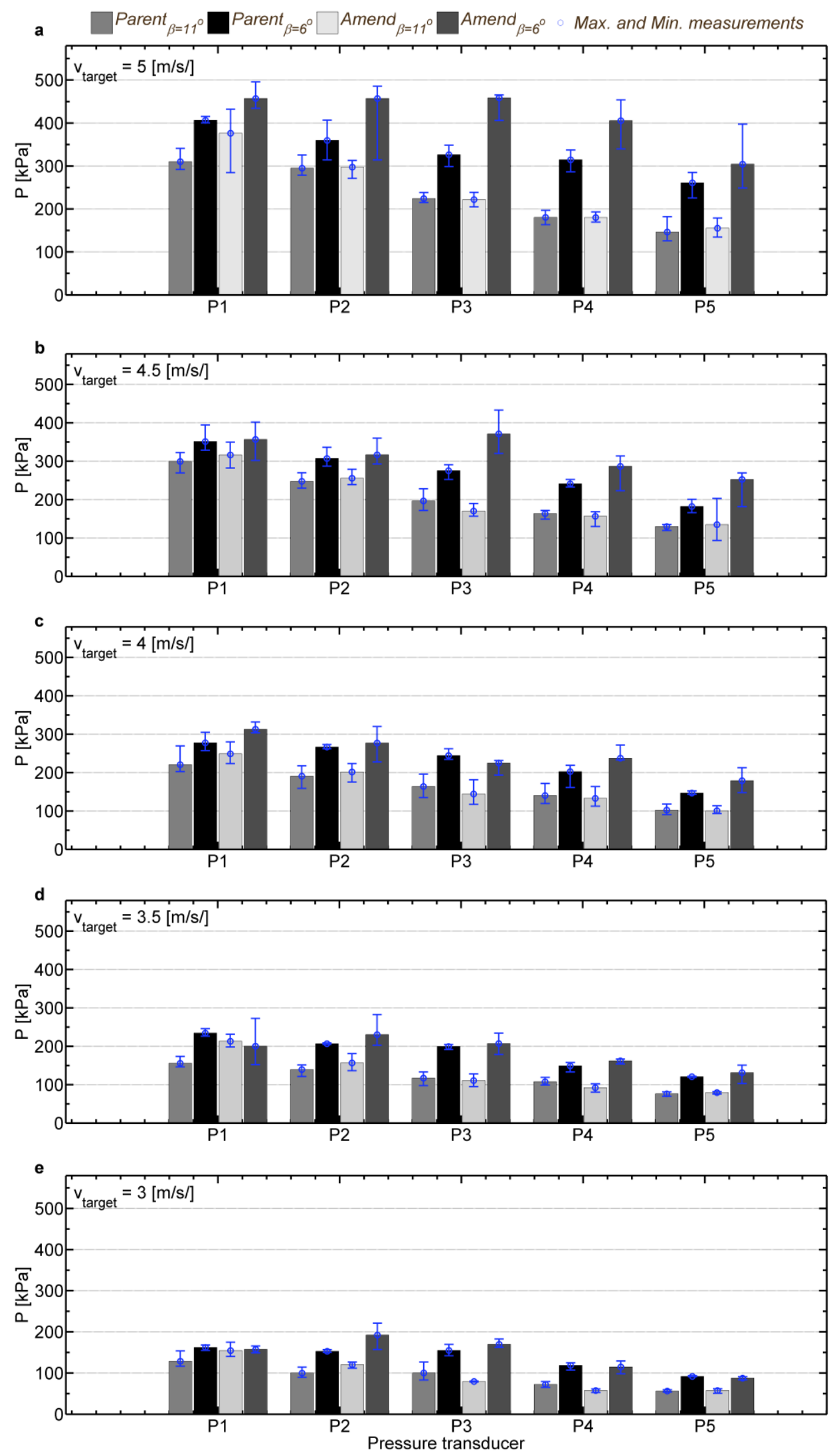

Fig. 14: Mean pressure distributions for all test conditions. 
For the test conditions using amended hull at $\theta=5^{\circ}$ no clear trend can be observed. This is attributed to water flow separation during water-entry causing more aerated water content. At target velocities of 4 and $5 \mathrm{~m} / \mathrm{s}$ the maximum pressure occurs at P1 with nearly constant value at $\mathrm{P} 2$ and $\mathrm{P} 3$. The pressure peak magnitude slightly drops at $\mathrm{P} 4$. In contrast at the target velocity of $4.5 \mathrm{~m} / \mathrm{s}$ the maximum pressure occurs at $\mathrm{P} 3$ and at $\mathrm{P} 2$ for the lower velocity impacts $(3$ and $3.5 \mathrm{~m} / \mathrm{s})$. The maximum pressure magnitude at P5 is lowest for all test conditions. This is attributed to the location of P5 being out of the enclosed volume beneath the wetdeck where the water can escape in multiple directions, hence a low pressure field is observed in comparison with the rest of the transducers (P1 to $\mathrm{P} 4)$ that are located in the vicinity of the arch closure.

It is interesting to note in Fig. 14 that using amended hull will lead increased maximum local pressure for both relative impact angles compared with the parent hull. Force analysis however, indicates the total vertical force decreases by approximately $6 \%$. The variation between the amended and parent hulls is attributed to the change in jet evolution during water entry that influences the pressure fields along the pressure transducer region.

The disconnect between peak pressure and peak total force between the amended and parent hull forms highlights the necessity to accurately consider 3-d pressure fields. Integrating pressures can lead to in-accurate force predictions, unless complete pressure mapping is available. To accomplish this experimentally for 3-d complex hull models is problematic. This observation matches the finding of Faltinsen et al. (1997) that large pressure peak magnitudes does not necessarily mean large stresses on the structure.

\section{Conclusions}

This work extended the three-dimensional water-impact tests using a controlled-speed servo-hydraulic slamming testing system to investigate the influence of centrebow geometry, relative impact angles and vertical velocity on hydrodynamic loads and corresponding pressure distributions.

A total of 64 successful water-impact tests were conducted on a catamaran hull model with two interchangeable centrebows at trim angles of $0^{\circ}$ and $5^{\circ}$ and at a range of vertical velocities of 3 to $5 \mathrm{~m} / \mathrm{s}$ in $0.5 \mathrm{~m} / \mathrm{s}$ increments. 
The smaller the relative impact angle, the bigger the area subjected to higher pressure fields and the more severe the vertical slam force. An increase of $5^{\circ}$ in trim angle can increase the vertical slamming force on the entire model by $30 \%$.

The results also demonstrate that the smaller the relative impact angle, the sharper the total slam force trace and the more significant the force peak. This finding illustrates the importance of considering relative impact angle carefully not only due to the higher the slam force magnitude but also for its shorter duration.

Bigger air-cushioning between wetdeck and water (due to separation) showed a slight decrease in the resultant force magnitude by approximately $6 \%$, achieved by using a winged amended centrebow.

Flow separation occurring during water-entry of 3-d body is followed by a reduction in the slamming forces. Stress concentration at certain locations in structures can therefore be avoided by separating flow prior to this location impacting.

The immersion corresponding to maximum slam force was found to be dependent on relative impact angle and independent of the relative velocity for large relative angles. This finding is in contrast to previous studies by Lavroff (2009) and Thomas et al. (2011b). However, both studies (past and present) agree that slam loads are strongly related to relative vertical velocity.

Strong relationships between impact velocity, water-entry angle, hull geometry and slam force were found and empirical relationships are proposed to estimate the slam force magnitude as a function of the impact velocity. These relationships are of importance for further validation studies to provide an estimate of the slam force for a broader range of relative impact velocities.

An increase in the pressure peak magnitudes in the vicinity of the semi-enclosed wetdeck void (surrounded by demihull and centrebow) for all conducted tests was observed, in comparison with the pressure transducer "P5" that is located out of that arch closure.

Larger peak pressure magnitudes do not necessarily lead to larger total forces. In addition pressure measurements at limited points should not be used in comparing 
between two hull performances, but through directly measuring the entire resultant forces or using strain gauges for local loads.

To decrease slamming forces on catamaran wetdeck structure, designers should look at increasing the relative impact angle between the arched wetdeck and water, decreasing the relative vertical velocity and/or avoiding arch closure by allowing water to easily escape from the archway closure.

\section{References}

Alaoui, A.E., Nême, A. and Scolan, Y.M. 2015. Experimental investigation of hydrodynamic loads and pressure distribution during a pyramid water entry. Journal of Fluids and Structures, 54, 925-935.

Alaoui, A.E.M., Nême, A., Tassin, A. and Jacques, N. 2012. Experimental study of coefficients during vertical water entry of axisymmetric rigid shapes at constant speeds. Applied Ocean Research, 37, 183-197.

Allen, T. 2013. Mechanics of Flexible Composite Hull Panels Subjected to Water Impacts. PhD, University of Auckland.

Battley, M., Stenius, I., Breder, J. and Edinger, S. 2005. Dynamic characterisation of marine sandwich structures, Springer, 537-546.

Battley, M. and Allen, T. 2012. Servo-hydraulic system for controlled velocity water impact of marine sandwich panels. Experimental Mechanics, 52(1), 95-106.

Chuang, S.-L. and Milne, D.T., 1971 DTIC Document, 1971. Drop tests of cones to investigate the three-dimensional effects of slamming.

Davis, M., Whelan, J. and Thomas, G. 2007. Computational modeling of wet deck slam loads with reference to sea trials. In: Proceedings of the Ninth International Conference on Fast Sea Transportation (FAST), Shanghai, China, 9.

Davis, M.R. and Whelan, J.R. 2007. Computation of wet deck bow slam loads for catamaran arched cross sections. Ocean Engineering, 34(17), 2265-2276.

De Backer, G., Vantorre, M., Beels, C., De Pré, J., Victor, S., De Rouck, J., Blommaert, C. and Van Paepegem, W. 2009. Experimental investigation of water impact on axisymmetric bodies. Applied Ocean Research, 31, 143-156.

Djatmiko, E.B. 1992. Hydro-structural studies on swath type vessels. PhD, University of Glasgow.

DNV, 2010 Det Norske Veritas (DNV), 2010. Environmental conditions and environmental loads, RP-C205, 106. 
Dobrovol'Skaya, Z. 1969. On some problems of similarity flow of fluid with a free surface. Journal of Fluid Mechanics, 36, 805-829.

Engle, A. and Lewis, R. 2003. A comparison of hydrodynamic impacts prediction methods with two dimensional drop test data. Marine Structures, 16(2), 175-182.

Faltinsen, O.M., Kvålsvold, J. and Aarsnes, J.V. 1997. Wave impact on a horizontal elastic plate. Journal of Marine Science and Technology, 2, 87-100.

French, B.J. 2012. Slamming of high-speed catamarans in irregular seas. $\mathrm{PhD}$, University of Tasmania.

Ge, C. 2002. Global Hydroelastic Response of Catamarans due to Wetdeck Slamming. $\mathrm{PhD}$, Norwegian University of Science and Technology.

Giannotti, J. 1975. Prediction of slamming loads for catamarans. In: Proceedings of the Seventh Annual Offshore Technology Conference, Houston, Texas, 348-357.

Greenhow, M. 1987. Wedge entry into initially calm water. Applied Ocean Research, 9, 214-223.

Jacobi, G., Thomas, G., Davis, M.R. and Davidson, G. 2014. An insight into the slamming behaviour of large high-speed catamarans through full-scale measurements. Journal of Marine Science and Technology, 19(1), 15-32.

Jalalisendi, M., Osma, S.J. and Porfiri, M. 2015. Three-dimensional water entry of a solid body: A particle image velocimetry study. Journal of Fluids and Structures, $59,85-102$.

Kaplan, P. 1987. Analysis and prediction of flat bottom slamming impact of advanced marine vehicles in waves. International shipbuilding progress, 34, 44-53.

Lavroff, J. 2009. The Slamming and Whipping Vibratory Response of a Hydroelastic Segmented Catamaran Model. PhD, University of Tasmania.

Lavroff, J., Davis, M., Holloway, D. and Thomas, G. 2013. Wave slamming loads on wave-piercer catamarans operating at high-speed determined by hydro-elastic segmented model experiments. Marine Structures, 33, 120-142.

Lewis, S.G., Hudson, D.A., Turnock, S.R. and Taunton, D.J. 2010. Impact of a freefalling wedge with water: synchronized visualization, pressure and acceleration measurements. Fluid Dynamics Research, 42(3), 035509.

Ochi, M.K. and Motter, L.E. 1973. Prediction of slamming characteristics and hull responses for ship design. Trans. Soc. Naval Archit. Mar. Eng, 81, 144-176.

Panciroli, R. and Porfiri, M. 2013. Evaluation of the pressure field on a rigid body entering a quiescent fluid through particle image velocimetry. Experiments in fluids, 54(12), 1-13. 
Payne, P.R. 1988. A discussion of the design pressures appropriate to the bottom of a planing boat. Ocean Engineering, 15, 471-493.

Rothe, F., Sames, P.C. and Schellin, T.E. 2001. Catamaran wetdeck structural response to wave impact. In: Proceedings of the International Conference of Fast Sea Transportation (FAST'01), Southampton, England, 125-133.

Stenius, I., Rosén, A., Battley, M. and Allen, T. 2013. Experimental hydroelastic characterization of slamming loaded marine panels. Ocean Engineering, 74, 115.

Swidan, A., Thomas, G., Ranmuthugala, D., Penesis, I. and Amin, W. 2014. Numerical investigation of water slamming loads on wave-piercing catamaran hull model. In: Proceedings of the $10^{\text {th }}$ Symposium on High Speed Marine Vessels (HSMV), Naples, Italy, 1-9.

Swidan, A., Thomas, G., Ranmuthugala, D., Penesis, I., Amin, W., Allen, T. and Battley, M. 2015. Prediction of Slamming Loads on Catamaran Wetdeck using CFD. In: Proceedings of the The $13^{\text {th }}$ international conference on fast sea transportation (FAST), Washington DC.

Swidan, A., Thomas, G., Ranmuthugala, D., Penesis, I., Amin, W., Allen, T. and Battley, M. 2016. Experimental drop test investigation into wetdeck slamming loads on a generic catamaran hullform. Ocean Engineering, In press.

Tassin, A., Jacques, N., El Malki Alaoui, A., Nême, A. and Leblé, B. 2012. Hydrodynamic loads during water impact of three-dimensional solids: Modelling and experiments. Journal of Fluids and Structures, 28, 211-231.

Thomas, G., Davis, M., Holloway, D. and Roberts, T. 2002. Extreme asymmetric slam loads on large high speed catamarans. In: Proceedings of the $6^{\text {th }}$ Symposium of High Speed Marine Vessels, Naples, Italy, 15-23.

Thomas, G., Kibby, L., Ford, A., Binns, J., Finnie, I. and Kavanagh, N. 2011 a. Experimental Investigation into Wave-Induced Design Loads on a Large Moored Catamaran. Ships and Offshore Structures, 6, 273-295.

Thomas, G., Winkler, S., Davis, M., Holloway, D., Matsubara, S., Lavroff, J. and French, B. 2011b. Slam events of high-speed catamarans in irregular waves. Journal of Marine Science and Technology, 16(1), 8-21.

Tveitnes, T., Fairlie-Clarke, A. and Varyani, K. 2008. An experimental investigation into the constant velocity water entry of wedge-shaped sections. Ocean Engineering, 35(14), 1463-1478.

Van Nuffel, D., Vepa, K., De Baere, I., Degrieck, J., De Rouck, J. and Van Paepegem, W. 2013. Study on the parameters influencing the accuracy and reproducibility of dynamic pressure measurements at the surface of a rigid body during water impact. Experimental mechanics, 53, 131-144. 
Van Nuffel, D., Vepa, K., De Baere, I., Lava, P., Kersemans, M., Degrieck, J., De Rouck, J. and Van Paepegem, W. 2014. A comparison between the experimental and theoretical impact pressures acting on a horizontal quasi-rigid cylinder during vertical water entry. Ocean Engineering, 77, 42-54.

Yettou, E.-M., Desrochers, A. and Champoux, Y. 2006. Experimental study on the water impact of a symmetrical wedge. Fluid Dynamics Research, 38, 47-66.

Yettou, E.-M., Desrochers, A. and Champoux, Y. 2007. A new analytical model for pressure estimation of symmetrical water impact of a rigid wedge at variable velocities. Journal of Fluids and Structures, 23, 501-522.

Zhao, R. and Faltinsen, O. 1993. Water entry of two-dimensional bodies. Journal of Fluid Mechanics, 246, 593-612.

Zhao, R., Faltinsen, O. and Aarsnes, J. 1996. Water entry of arbitrary two-dimensional sections with and without flow separation. In: Proceedings of the $21^{\text {st }}$

Symposium on Naval Hydrodynamics, Washington DC, USA, 408-423. 